\title{
Sustainability improvement of traditional cropping system in Uttarakhand, India, through intercropping with medicinal and aromatic plants
}

\author{
Madhulika Pandey*, B. P. Nautiyal and Nirdesh Kumar
}

Crop production in mountain agriculture is in steady decline (5\%-30\%) over the past few decades. Only few species of cereals, pulses, potato, amaranth, etc. are important cash crops in the hilly regions of Uttarakhand, India. In traditional hill cropping systems, framers grow sesame, black soybean, corn, proso millet, amaranth, Brassica spp, etc. as mixed crop. These types of traditional cropping systems are not much advantageous and do not meet the requirements of the existing population. In the hilly regions Perilla, Hedychium, turmeric, industrial hemp, lemon grass, citronella, lavender, belladonna and other medicinal and aromatic plants (MAPs) have immense potential. However, they are still not a part of the cropping system. Introduction of these MAPs as intercrops with traditional crops will not only improve the production potential of main crops, but also generate additional income to the farming family. Besides immense cash value, these plants also have less/no threats from wild animals. Similarly, introduction of medicinal and aromatic crops with horticultural crops is one of the key options to enhance agriculture production, as topography and climate of Uttarakhand is suitable for growth of these crops.

Keywords: Intercropping, medicinal and aromatic plants, sustainability, traditional cropping system.

UTTARAKHAND, the 27 th state of the India comprising the Central Himalaya, is spread over an area of 53,483 sq. km (ref. 1). Uttarakhand is also known as 'Devbhoomi' due to its scenic beauty, temples and religious places. Nearly $80 \%$ of land in the state is in the hilly region, of which $24 \%$ land accounts for total cropped area. The net sown area is around $12 \%$ and therefore is under pressure to sustain $80 \%$ of the rural population. Agriculture sector employs more than $44 \%$ of workers and provides livelihood security to a major proportion of the rural population ${ }^{2}$. In the Himalayan region, wheat, rice, maize, millets, barley, few species of pulses, oilseeds, potato, Ramdana (amaranth), kuttu/ugal (buckwheat), etc. are important cash crops. However, Uttarakhand has more area under millets and pulses. The state is well known for its horticultural crops, which include offseason vegetables, floriculture crops, as well as medicinal and aromatic plants (MAPs). In temperate zone of the state, only kharif crops are grown due to very cold

Madhulika Pandey and B. P. Nautiyal are in the Institute of Medicinal and Aromatic Plants, VCSG Uttarakhand University of Horticulture and Forestry, Mehalchori, Gairsain 246 431, India; Nirdesh Kumar is in the Syngenta India Ltd., Indore 452 010, India.

*For correspondence. (e-mail: pandey.madhulika@hotmail.com) climate. Despite the abundance of natural resources, most people of the state are marginalized and still live on a subsistence level ${ }^{3}$. Thus, agricultural advancement is the most important challenge in Uttarakhand due to its natural constraints (Figure 1).

Crop production in hill agriculture is in steady decline $(5 \%-30 \%)$ over the past few decades ${ }^{4}$. In the past four decades, human population has increased up to 2.7 fold in the Indian Himalaya with an annual increase of $4.19 \%$,

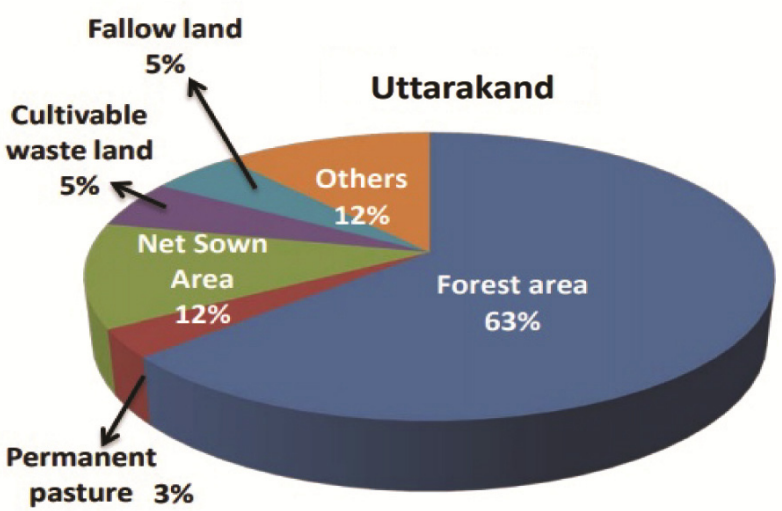

Figure 1. Land utilization pattern of Uttarakhand. Source: Uttarakhand Socio-Economic Mirror, 2016. 
whereas improvement in crop production is negligible or declining gradually ${ }^{5}$. In mountain ecosystem, the potential of land-based activities has reached its maximum limit. Farmers in the hilly regions experience low production potential and resource use efficiency due to short growing season, small land holdings, moisture stress, poor soil conditions, remoteness, inaccessibility, poor production, post-production management, lack of market development and entrepreneurship. All these natural and socioeconomic constraints have led to under-utilization of resource bases in the hills. People living in the mountain region have limited livelihood options for their daily needs from existing traditional cropping systems. Therefore, there is growing demand to modify the existing traditional cropping system to make it more productive.

\section{Cropping systems in Uttarakhand}

Cropping systems, represent a cropping pattern (proportion of area under various crops at a point of time in a unit area) used on a farm and its interaction with farm resources, other farm enterprises and available technology. In the cropping systems, sometimes several crops are grown together, or they are grown separately at short intervals in the same field. In the hilly region of Uttarakhand, various agro-climate zones along the altitudinal gradient, viz. (i) lower altitude (up to $1200 \mathrm{~m}$ ), (ii) middle altitude (between 1200 and $2200 \mathrm{~m}$ ) and (iii) higher altitude (above $2200 \mathrm{~m}$ ) are found.

The cultivated land of agro-climate zone is mainly divided into three categories ${ }^{6}$ : (a) katil - land of forest edges, (b) upraon - land of hillsides, and (c) talaonland of valley bottom.

Crops growing seasons followed in the agro-climate zones of Uttarakhand include: (a) chaumas or baskat/ kharif (rainy season; mid-June to October), (b) hyund or sheetkal/rabi (winter season; November to February), (c) purior kharso/jayad (hot weather season). This period can be divided into two: (i) Spring season (March-June): Kitchen gardens, side of cultivated lands, fields near houses are used for growing mainly vegetables. (ii) Hot summer season (May-June): Mainly irrigated fields are used for the cultivation of cheena (proso millet) and makki (corn) in this growing season. After harvesting of these crops, paddy is transplanted in the fields.

\section{Major crops grown in Uttarakhand}

- Grains/millets: Paddy, mandua (finger millet), jhangora (barnyard millet), ramdana (amaranth), kuttu/ugal (buckwheat), jowar/bajur (sorghum), makki (corn) and cheena (proso millet).

- Pulses and beans: Rajma (kidney bean), lobia (blackeyed peas), bhatt (black soybean), gehat (horse gram), naurangi (cowpea), urad (black gram), mung (green gram), arhar/tur (pigeon pea) and masoor (lentil).

- Oilseeds: Til (sesame), bhangjeera (perilla), sunn (sann hemp), bhang (industrial hemp), sarson (Brassica spp.).

- Vegetables: Cholai (amaranth), kheera/kakari (cucumber), lobia (black-eyed peas).

- Spices: Jakhya (Cleome viscose), til (sesame).

The following crop rotation and mixed cropping systems are adopted in the hills of Uttarakhand.

\section{Crop rotations}

The traditional methods of crop rotations of Uttarakhand are as follows

- Potato-wheat-potato

- Proso millet-paddy-wheat

- Proso millet-paddy-potato

- Corn-paddy-wheat

- Lentil-paddy-wheat

- Finger millet/barnyard millet-paddy-wheat

- Potato-chilli-tomato

- Radish-finger millet-red chilli

- Buckwheat-turmeric-fenugreek

\section{Mixed cropping}

The indigenous cropping system involves sowing of multiple locally well adopted crop seeds in a single terraced field during the kharif/chaumasa or monsoon season, which enables the farmers to supply different kinds of foods, maintaining crop biodiversity, restoring soil fertility (by the use of leguminous plants), reducing the infection of pests and pathogen. It is predicted that multiple cropping helps in increasing production per unit area and per unit time, which needs scientific validation. This is also known as baranaja system of mixed cropping.

Important mixed cropping systems of Uttarakhand are as follows:

- Paddy + kauni (foxtail millet) + jhangora (barnyard millet $)+$ jowar (sorghum) + til (sesame) + urad (black gram $)+$ kakri (cucumber) + muli (radish) + kuttu/ugal (Buckwheat).

- Paddy + til (sesame) + kauni (foxtail millet).

- Paddy + til (sesame) + kauni (foxtail millet) + makki $($ corn $)+$ raiyas (rice bean) + bhindi (lady's finger $)+$ muli (radish).

- Paddy + soybean + urad (black gram) + kakri (cucumber) + kauni (foxtail millet) + muli (radish) + kuttu/ugal (Buckwheat).

- Makki (corn) + bhindi (lady's finger) + muli (radish) + lobia (black-eyed peas). 
- Madua (finger millet) + jowar (sorghum) + bhatt (black soybean) + urad (black gram) + lobia (black-eyed peas) + Ramdana/chua (amaranth).

- Jhangora (barnyard millet) + madua (finger millet) + bhatt (black soybean) + jowar (sorghum).

- Wheat + matar (pea) + sarson (Brassica $\mathrm{spp})+$ chana (chickpea) + jau (barley).

- Jau (barley) + matar (pea) + sarson (Brassica spp) + chana (chickpea) + masoor (lentil).

\section{Limitations of traditional cropping system}

As mentioned earlier, the indigenous cropping system involves sowing of multiple crop seeds in a single terraced field. In this traditional mixed cropping system, crops are grown without any definite proportion or pattern. Mixed cropping is practised in traditional subsistence farming to meet the domestic needs of the farmer's family. Even though crops in the mixed cropping meet the farmer's family needs, the yield potential of crops are very low due to competition between them for water, light, nutrients, etc. In this traditional cropping system, farmers spend almost nothing on inputs, viz. seed, organic fertilizer, irrigation, pest control measures, etc. Whenever they find the crop sowing conditions suitable, they start planting. Land holdings of farmers in the Himalayan region are very small and fragmented too. Sowing of various types of crops altogether in a single terraced field makes the soil infertile by extracting the same mineral nutrients from soil. So, this traditional cropping system was not beneficial to the farmer not only in terms of profit generation as well as to the health of the community and environment.

Crops like jhangora (barnyard millet), madua (finger millet), til (sesame), kuttu/ugal (buckwheat), bhatt (black soybean), makki (corn), chana (chickpea), urad (black gram), cheena (proso millet), Ramdana/chua (amaranth), sarson (Brassica spp.), etc. have greater potential as cash crops, but in the mixed cropping system their yield potential is very low due to lesser plant population. So cash crops like millets, pulses, oilseeds and vegetables can be widely produced keeping climate and terrain under

Table 1. Productivity (kg/ha) of major crops (2014-15)

\begin{tabular}{lcc}
\hline Crops & India & Uttarakhand \\
\hline Rice & 2381 & 2260 \\
Wheat & 3033 & 1881 \\
Maize & 2580 & 2177 \\
Total coarse cereals & 1629 & 1414 \\
Gram & 889 & 824 \\
Total pulses & 733 & 791 \\
Rapeseed and mustard & 1170 & 685 \\
Total oilseeds & 1148 & 907 \\
Total food grain & 2070 & 1823 \\
\hline
\end{tabular}

Source: Agricultural Statistics at a Glance 2015, Department of Agriculture, Cooperation \& Farmers Welfare; Uttarakhand Statistical Diary. consideration. However, due to topographic conditions, small land holdings, poor soil conditions, unavailability of inputs, viz. improved seed, fertilizer, irrigation, pest control measures, etc. the productivity potential of these cash crops, except pulses, is very low in sole planting compared to the national average (Table 1).

Due to these topographic, climatic and socio-economic constraints, crop diversification is necessary, i.e. introduction of more income-generating crops such as MAPs as intercrops in the existing cropping system, which not only meets the requirements of the farmer's family, but also helps generate additional income and improves their livelihood.

\section{Crop diversification}

The variations in altitude and climate offer natural advantage for crop diversification in the hills. In Uttarakhand most of the area under extensive forest cover, horticultural and vegetable crops but has limited area under arable farming and industrialization. However, it is to be noted that the state's share in the total area under fruits and vegetables of the country was $2.88 \%$ and $0.96 \%$, but share in production was only $0.99 \%$ and $0.65 \%$ respectively, in 2012-13. This indicates low productivity of these crops $^{7}$. As such, alternative strategies for agriculturerelated enterprises, viz. field crops, forest crops, horticultural and floricultural crops need to be strengthened. A better cropping system can be developed by adopting MAPs as intercrops along with the major crops (field crops, forest crops, horticultural and floricultural crops) in the existing crop rotation and mixed cropping system. In the existing cropping system, less remunerative crops can be replaced by more profitable crops on a rotational basis and less remunerative crops required to meet the farmer's family needs could still be grown on the field bunds, field borders and in the backyard of homes. Utilization of fallow lands may also provide additional gains.

Crop diversification aims to maintain current levels of cropped area under food and related crops while incorporating MAPs as additional crops in the existing cropping system as intercrops, crop rotations, etc. ${ }^{8}$. Intercropping involves growing of two or more crops simultaneously on the same piece of land (field) with a definite proportion or row pattern. This is crop intensification in both time and space dimensions. Intercropping results in optimum crop geometry compared to mixed cropping, which is one of the important factors for higher production by utilizing the underground resources efficiently and harvesting solar radiation as much as possible and in turn resulting in better photosynthetic activity ${ }^{9}$. Intercropping systems not only improve production potential, but also generate higher profits from the lands and also pave the way for agro-based enterprises in the region ${ }^{10,11}$. 
The Himalaya has a large genetic diversity of crop species as well as landraces indigenously developed by farmers of the region. In the hilly regions, bhangjeera (Perilla), kapoorkachri (Hedychium), haldi (turmeric), bhang (industrial hemp), neembu ghass (lemon grass), java ghass (citronella), lavender, belladonna and other MAPs have immense potential. However, they are still not part of the cropping system. MAPs can be cultivated in order to obtain essential oils and fragrant chemicals, which are upstream elements of food, flavour and cosmetic industries. They are mainly used in Ayurvedic preparations and are in short supply from traditional source. The demand for MAPs is increasing day by day at the national as well as international markets. Therefore, intercropping of MAPs along with major cash crops shall be advocated and adopted for obtaining additional income for the farmers. The wide spacing available in horticultural and forest tree type of plantations facilitates the cultivation of MAPs as intercrops to generate additional income to farmers. Short-cycled MAPs and culinary herbs are suited for short-term intercropping during juvenile phase of horticultural and forest trees. Shade-tolerant and rhizomatic MAPs can be grown on a long-term basis in widely spaced plantations.

MAPs are well adapted to partial shading, moist soil, high relative humidity and mild temperatures ${ }^{12}$, allowing them to be intercropped with timber and fuel wood plantations, fruit trees and plantation crops. Some well-known MAPs that have been successfully intercropped with fuel wood trees (e.g. katha (acacia), siris (Lebbek tree), eucalyptus, gamhar (white teak) and subabool (wild tamarind) in India include kalmegh (andrographis), aswagandha (Indian ginseng), safed musli (Indian spider plant), Rauvolfia turmeric, wild turmeric, kali musli (golden eye grass) and ginger ${ }^{13,14}$. Besides immense cash value, these MAPs also have less/no threats from wild animals.

\section{Medicinal and aromatic plants-based cropping pattern and intercropping systems}

Intercropping of MAPs with other crops has been reported earlier. Citronella intercropped with pigeon pea $(2: 2$ and $2: 1$ row ratio) results in significantly higher $B: C$ ratio and higher values of land equivalent ratio (LER), indicating 3\%-8\% economic advantage over sole planting ${ }^{15}$. Geranium intercropped at different row strips $(1: 1$ and $1: 2)$ and plant density $(60 \times 45,75 \times 45$ and $90 \times 45 \mathrm{~cm}$ ) with potato results in maximum economic returns at $1: 2$ row strip for all planting densities ${ }^{16}$. Similar trends of monetary advantages of other aromatic crops by inclusion of pulses, vegetables and cereals have been reported $^{17-19}$. Patchouli + black gram, patchouli + soybean, patchouli + French bean and patchouli + lady's finger intercropping systems did not affect total biomass yield and total essential oil yield of patchouli, and yielded
$0.40,0.35,5.40$ and $4.50 \mathrm{tha}^{-1}$ respectively, over and above that of sole planting of patchouli crop. Maximum economic returns were obtained with patchouli + French bean (Rs 166,470) followed by patchouli + lady's finger (Rs 151,770) intercropping system ${ }^{20}$. Finger millet + pigeon pea (4:1 row ratio) intercropping system resulted in higher finger millet equivalent yield compared to sole planting of finger millet ${ }^{21}$.

There was significant improvement in morphological and yield-attributing features of turmeric under som (Persea bombycina Kost.) trees than in open condition which resulted in the scorching of turmeric leaves, lesser morphological growth and less production of rhizomes from a unit area ${ }^{22}$. A multistorey intercropping system of mango with four component crops, viz. bay, black pepper, pineapple and ginger gave $91 \%-143 \%$ more net returns over the monocrop of mango ${ }^{23}$. Under the shade of juvenile (8-10-yr-old) mango trees, ginger, turmeric and colocasia generated higher gross return, net return and $\mathrm{B}$ : C ratio compared to adult mango trees and sole planting of mango ${ }^{24}$.

All these studies showed that there is also a need to develop MAPs-based cropping pattern and intercropping systems to meet the needs of the farmer's family and to improve the socio-economic condition of farmers in the hilly regions of Uttarakhand.

\section{Conclusion}

The present study aimed towards improvement in socioeconomic condition of Uttarakhand farmers through introduction of MAPs as intercrops in the existing cropping system. Diversification in existing cropping system through introduction of MAPs will be helpful to meet the needs of the farmer's family as well as to improve the livelihood. MAPs-based intercropping system has the potential to develop Uttarakhand as a 'herbal state', if available technology could be transferred wisely from lab to field.

1. Census of India, 2001; www.censusindia.gov.in

2. Nautiyal, R. R. and Datta, R., Development Dynamics of a Himalayan State, 2018, p. 97.

3. Singh, J., Sustainable development in Indian Himalayan region: linking ecological and economic concerns. Curr. Sci., 2006, 90, 784-788.

4. Pratap, T. and Watson, H., Slopping agriculture land technology (SALT). A regenerative option for sustainable mountain farming. ICIMOD Occasional, Paper No. 23, International Centre for Integrated Mountain Development, Kathmandu, Nepal, 1994.

5. Nandy, S. N. and Rao, K. S., Land use pattern and population pressure in Uttaranchal. ENVIS Bull. Himalayan Ecol. Dev., 2001, 9, 17-23.

6. Negi, K. S. and Pant, K. C., Genetic wealth of agro-horticultural crops, their wild relatives, indigenous medicinal and aromatic plants of UP Himalayas. J. Econ. Taxon. Bot., 1993, 8(1), $17-41$. 
7. Tuteja, U., Agriculture profile of Uttarakhand Agricultural Economics Research Centre, University of Delhi, 2015.

8. Prakasa Rao, E. V. S., Medicinal and aromatic plants for crop diversification and their agronomic implications. Indian J. Agron., 2009, 54, 215-220

9. Thavaprakash, N., Velayudham, K. and Muthukumar, V. B., Effect of crop geometry, intercropping systems and integrated nutrient management practices on productivity of baby corn (Zea mays L.) based intercropping systems. Res. J. Agric. Biol. Sci., 2005, 1, 295-302.

10. Kumar, S. and Patra, D. D., Integration of mediculture with agriculture for sustainable higher productivity, profits and employment. J. Med. Aromat. Plant Sci., 2000, 22, 751-754.

11. Rajeswara and Rao, B. R., Biomass yield, essential oil yield and essential oil composition of rose scented geranium (Pelargonium sp.) as influenced by row spacing and intercropping with corn mint. Ind. Crops Prod., 2002, 16, 133-144.

12. Vyas, S. and Nein, S., Effect of shade on the growth of Cassia ungustifolia. Indian For., 1999, 125, 407-410.

13. Mishra, R. K. and Pandey, V. K., Intercropping of turmeric under different tree species and their planting pattern in agroforestry systems. Range Manage. Agrofor., 1998, 19, 199-202.

14. Prajapati, N. D., Purohit, S. S., Sharma, A. K. and Kumar, T., A Handbook of Medicinal Plants. Agribios, India, 2003, p. 553.

15. Ansari, M. H., Verma, B. K., Ansari, M. A., Mishra, D., Srivastava, A. K., Khan, N. and Mohd. Saquib, Impact of cropping pattern on growth, yield attributes and system productivity of citronella (Citronella winterianus) pulses intercropping system in Central India. Indian J. Agric. Sci., 2015, 85, 392-396.

16. Verma, R. K., Yadav, A., Verma, R. S., Laiq-Ur Rahman and Khan, K., Intercropping of aromatic crop Pelargonium graveolens with Solanum tuberosum for better productivity and soil health. J. Environ. Biol., 2014, 35, 1165-1171.
17. Tajuddin, Saproo, M. L., Yaseen, M. and Hussain, A., Productivity of rose (Rosa damascene Mill) with intercrops under temperate conditions. J. Essent. Oil Res., 1993, 5, 191-198.

18. Verma, R. K. et al., Biomass yield, essential oil yield and resource use efficiency in geranium (Pelargonium graveolens L. Her. ex. Ait), intercropped with fodder crops. Arch. Agron. Soil Sci., 2013, 55, 557-567.

19. Verma, R. K., Verma, R. S., Chauhan, A., Singh, A., Rahman, L. and Kalra, A., Biomass yield, essential oil yield and quality of rose-scented geranium (Pelargonium graveolens L. Herit) intercrop with vegetables. Int. J. Agric. Res., 2011, 6, 830-839.

20. Singh, M., Influence of spacing and intercropping on biomass and essential oil yield of patchouli (Pogostemon cablin (Blanco) Benth.). J. Spices Aromat. Crops, 2008, 17(3), 235-239.

21. Ved Prakash, Chandra, S. and Shrivastava, A. K., Relay cropping of wheat in finger millet + pigeon pea intercropping system under rainfed condition in mid-hill of North-West Himalaya. Indian J. Agric. Sci., 2005, 75, 676-678.

22. Hazarika, U., Dutta, R. K. and Chakravorty, R., Morphology and yield attributing features of ginger and turmeric under natural shade of som (Persea bombycina Kost) plants. Adv. Plant Sci., 2009, 22(1), 115-117.

23. Awasthi, O. P. and Saroj, P. L., Economic analysis of mango multistrata intercropping. Trop. Sci., 2004, 44, 43-47.

24. Haque, M. E., Roy, A. K. and Sikdar, B., Performance of ginger, turmeric and mukhi kachu under shade of mango orchard. Hortic. J., 2004, 17(2), 101-107.

Received 2 June 2019; revised accepted 23 July 2019

doi: $10.18520 / \mathrm{cs} / \mathrm{v} 117 / \mathrm{i} 8 / 1281-1285$ 